\title{
Using Video in Research with Young Children, Teachers and Parents: Entanglements of Possibility, Risk and Ethical Responsibility
}

Profiling Emerging Research Innovations

\author{
Maggie Haggerty \\ Senior Lecturer, Faculty of Education, Te Herenga Waka / Victoria University \\ of Wellington, Wellington, Aotearoa / New Zealand \\ maggie.haggerty@vuw.ac.nz
}

\begin{abstract}
This article draws on research conducted for the author's PhD study and concepts in semiotic multimodality and relational materialism (Barad, 2007; Haraway, 2008) to explore the dynamics of what partnering with video/visual technologies in educational research with young children can be, do and become. This study was an ethnographic study which examined the curriculum and assessment priorities six focus children in Aotearoa-New Zealand encountered during their last six months in an early childhood (EC) centre and their first six months at school. In the article the author focuses on two video-recorded observations included in the $\mathrm{PhD}$ report by way of opening up for critical consideration the entanglements of possibility, risk and ethical responsibility entailed in the use of video in research with young children.
\end{abstract}

\section{Keywords}

emerging research innovations - video - entanglements - young children - ethics multimodality - relational materialism 


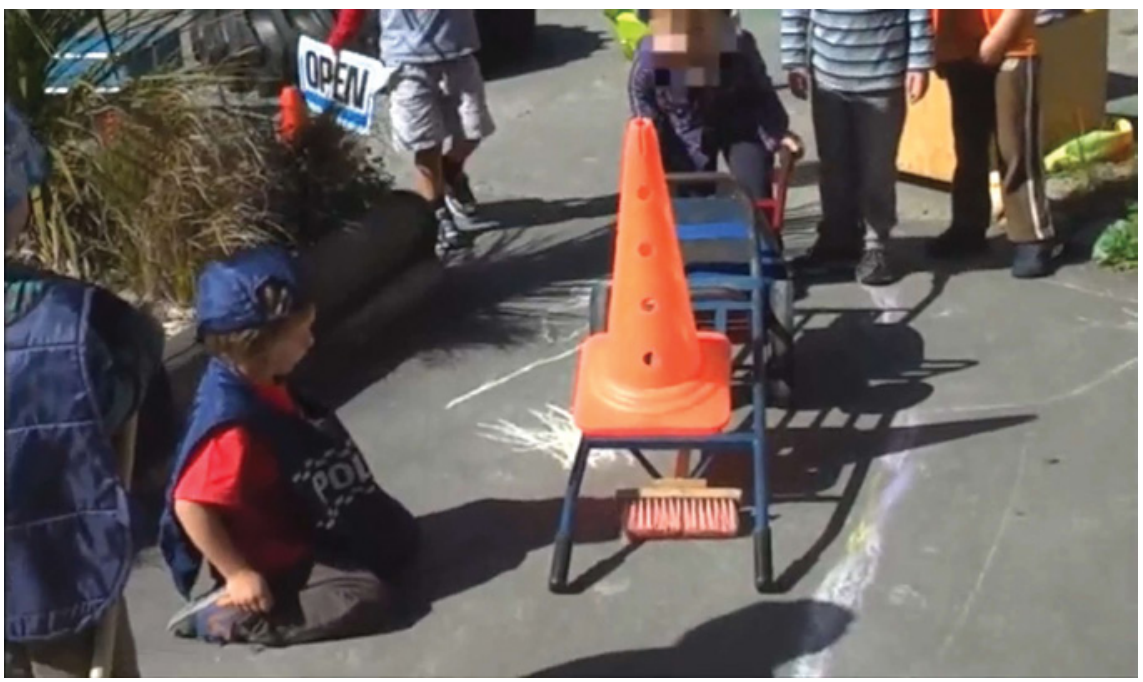

FEATURE Maggie Haggerty's article comprises two videos, which can be viewed here and here.

- This article is part of the special topic 'Profiling Emerging Research Innovations', edited by Elaine Khoo.

\section{Introduction}

The use of cameras, whether operated by children (Kind, 2013; Magnusson, 2018) or by researchers (Flewitt, 2006), has been framed by researchers in and beyond education as instrumental in giving voice to children's perspectives. It is frequently promoted as having the potential to introduce content and topics "otherwise overlooked or poorly understood from an adult viewpoint" (Luttrel, 2010, p. 225). Opportunities for participants to view and respond to video observations are also highlighted as facilitating possibilities for enhanced participant input. In education research video recordings have been utilised as a platform for inviting participants into dialogue about matters not opened up by relying on written descriptions and conversations alone (Otrel-Cass, Cowie \& Maguire, 2010). Viewing video/visual material has been seen as a way of helping "rouse", "refame" (Luttrell, 2010, p. 225) and democratise (Magnusson, 2018) conversations about children's teachers' and parents' understandings and experiences. These were the sorts of possibilites inspiring the take up of video in my study and the sorts of possibilites I seek to explore in this article. 
Alongside such possibilities come questions about the amount of power video puts in the hands of the researcher, and concerns over how close an inspecting gaze video allows. These issues continue to feature prominently in ethical discussions in the education research literature-particularly, but not only, where involving young children (De Freitas, 2013; Sparrman \& Lindgren, 2010; Stephenson, 2010; Rutanen, Amorim, Marwick \& White, 2018). Such issues resonate strongly with the sorts of concerns Foucault (1977/1995) raises over apparatuses of observation serving as mechanisms of surveillance and control.

The choice to use video-recorded observations in my $\mathrm{PhD}$ research (and its dissemination) (Haggerty, 2019) began with the aim of enabling more inclusive opportunities for involving children in research in ways their activities could do more of the talking, not just their words (Sellers, 2009). This endeavour to expand the analytic frame, by moving closer to the ontology of bodies and events and focusing on children's ways of being, doing, knowing and relating, was aimed at challenging two orthodoxies which have impacted particularly reductively on the way in which the lifeworlds and capacities of very young children are perceived: classical mind-body dualism and the view that "all that is truly thinking must be linguistic" (Haraway, 2008, p. 371). My quest for a more central focus on being and doing as ways of knowing and becoming was hence aimed at providing an opportunity for "rethinking what forms of intelligence, truth and expertise count" (Lorimer, 2010, p. 238).

In the sections that follow I first briefly discuss the ontological turn in multimodality discourse that informs the line of thinking I draw on in this article, before turning to the two videoed events the remainder of the article is based around. These were amongst a number of videoed events included in the thesis as cases to think with about the focus of my wider study. This was to critically examine the curriculum and assessment priorities operating in each setting, the particular modes of being, doing, knowing and relating these priorities promoted or made difficult, and how such priorities related to those of the teachers and the focus children and their parents. Data drawn on in the wider study included videoed observations and fieldnotes, interviews with the teachers, the focus children and their parents, and curriculum- and assessmentbased, policy- and practice-related documentation.

The first videoed event is from the EC setting which all six focus children attended, and centres around four-year-old Jacob (all names are pseudonyms). Particular interests here include the opportunities video opened up for engaging with children's often underexplored modes of being, doing, knowing and becoming, and the chance to explore-albeit in a small way-thinking with 
(Mazzei \& McCoy, 2010) DeleuzoGuattarian/Baradian ideas about self-and relations, and the concept of human and more-than-human relations as mutually co-constitutive (Deleuze \& Guattari, 1987; Barad, 2007; Colebrook, 2002). The second videoed event takes place in one of the two new entrant (reception) classrooms in the study (each in different schools), and centres around fiveyear-old Sabal, the only child from the study EC centre to attend this school. The point of focus here includes both the analytical insights into peer and classroom dynamics this videoed event helped generate, and the possibilities, risks and ethical questions that opened up in relation to its viewing.

2

\section{Researching with Video: The Ontological Turn in Theorisations of Bodies and Technologies}

Research in the field of multimodal ethnography (Kress, 2000) has helped bring much needed attention to the transformative role video technology has played in broadening understandings of how different modes such as movement and vocalisations are used in combination in human meaning-making (Flewitt, 2006). McNeill (2000), in the field of gestural studies, for example, has argued that without the advent of video technology, the study of gesture in relation to other modes "would scarcely be possible" (p. 9). Other researchers seeking to theorise the capacities contributed by non-human technologies/resources have utilised and extended the concept of affordance (Mangen, 2010), a concept Kress (2000) initially made popular in multimodal discourse as a way into thinking about the distinctive capacities of different modes for human meaning-making. For example, the different ways of knowing made possible by seeing or doing something rather than being told about it.

Such efforts to theorise agency as distributed are currently being pushed considerably further by the endeavour in recent scholarship-variously referred to as the ontological turn, relational materialism and posthuman research (Dolphijn \& van der Tuin, 2012; Taylor, 2016) — to more fully account for the semiotic force, generative agency, and constitutive role of the material, of and beyond the corporeality of the human body (Barad, 2007). From this perspective, the line of thinking I seek to explore in a small way in this article, a focus on the research use of video requires attending to the ways in which significance is owed in part (sometimes in large part) to the generative force of the technologies themselves (Änggård, 2013). In this view the semiotic focus is shifted or decentred from the tendency in multimodality discourse to focus centrally and sometimes exclusively on human meaning making and the agency of the human-subject-as-meaning-maker. Here the focus becomes what 
Barad frames as giving matter its due and the real world implications or (worldproducing) differences such human and more-than-human relationships bring into effect (Alaimo \& Hekman, 2008; Barad, 2007). Haraway (2008), for example, frames such relational entanglements as an "infolding" in which human bodies and technologies co-habit each other, and in which technology is a "full partner" (p. 249).

\section{3}

\section{Working with Video: The Research Process and Ethics}

In following other researchers endeavouring to work ethically when working with video in research (Rose, 2012), particularly with young children (Flewitt, 2005a), I sought to treat consent as provisional, continuously checking in and actively monitoring that participants were comfortable with how things were proceeding, rather than as "a once-and-for all event at the start of the research" (Rose, 2012, p. 335). I spent a total of about two half-days videoing each focus child when at the EC centre, and in negotiation with the children, teachers and parents, either one or two half-days when they were at school.

Video use in this study included an undertaking to pass back to participants (teachers, focus children and their parents), copies of their video-recorded observations to view and sign off (consent to use for publication). In this way teachers, focus children and their parents were able to request the editing out of any material they did not wish more widely disseminated, and were, in addition, actively encouraged to take up opportunities to offer written and/or verbal feedback. In light of the limitations on children's capacity to take up these opportunities I tried actively encouraging adult participants (parents and teachers) to act alongside me as children's advocates. That is to check in with and actively monitor children's experiences of the research process especially in relation to the process of being videoed and the content of videorecordings. An issue here however, as I return to discuss in later sections, was how to avoid falling into treating children's and adults' interests and perspectives as one and the same.

Anonimising video data started with sounding over all names. Faces were generally left identifiable, but were blurred out either as per the terms of consent, or where thought to be in the best interests of the participant. Decisions over the latter tended to be arrived at in consultation with participants and/or with my supervisors.

In data analysis I sought to pay attention to the corporeality of the body and modes of operating highlighted as important in the multimodality literature (Kress 2000, 2011): gaze, posture, facial expression, gesture, movement, action 
(Franks \& Jewitt, 2001), sounds, vocalisations, words/language (Flewitt, 2005b), proxemics and manipulations (Wohlwend, 2011). In endeavouring to put relational materialist thinking to work in addressing the entangled nature of relations involving self and other (Barad, 2007), I tried thinking with the Baradian/Deleuzian/DeleuzoGuattarian-derived concept of self-and or "bodyand"-relations (Leander \& Boldt, 2012. p. 29), aiming for my exploration of children's day-to-day “curriculum-ing” (Sellers, 2009, p. 1) to include a focus on the inter/intra-activity of human and more-than-human. Following Barad's (2007) invocation to attend to the relations of researcher, researched, research tools and research data as co-constitutively intertwined-or as Barad proposes intra-actively entangled-I also sought ways to attend to the operation of these research-related entanglements. This included but was not limited to the research use of video.

Episode One: The Broom-machine: Jacob

The broom-machine episode was one of numerous videoed events helping provide useful insight into day-to-day curriculum activity at the EC centre. It was, for example, a way into more fully engaging with the sheer amount of doing typically going on in this setting and how this conjoined with the often generous expanses of time/space available for children to choose what and with whom they became involved. It also and importantly offered an enhanced, if fleeting, opportunity to engage with what Jacob identified in his final interview were key priorities for him at the EC centre: "playing and making stuff, like making machinery" and "friends". This was, in a small way, both an opportunity to engage differently with the dynamic and multiple modes that are "the very specificity of each person" (Davies, 2014, p. 1), and a call to revisit notions of pedagogy premised on the idea of humans "as the measure of all things" (Haraway, 2008, p. 74).

The video excerpt starts as four-year-old Jacob proposes to playmates nearby that the vehicle they have put together needs a broom: "so you can sweep around...”. When he receives a welcoming response from the vehicle operator: "Thanks [Jacob]. I needed you", Jacob proceeds with carrying out his idea of attaching a broom. However there is disagreement over the way he attaches it. The operator of the vehicle insists: "I can't have it like that though", and repositions it. Jacob, now contemplating the workings of the repositioning (See Figure 1), asks: "What happens when you go forward?". As is seen in the video clip below, the answer comes from the broom-machine. 


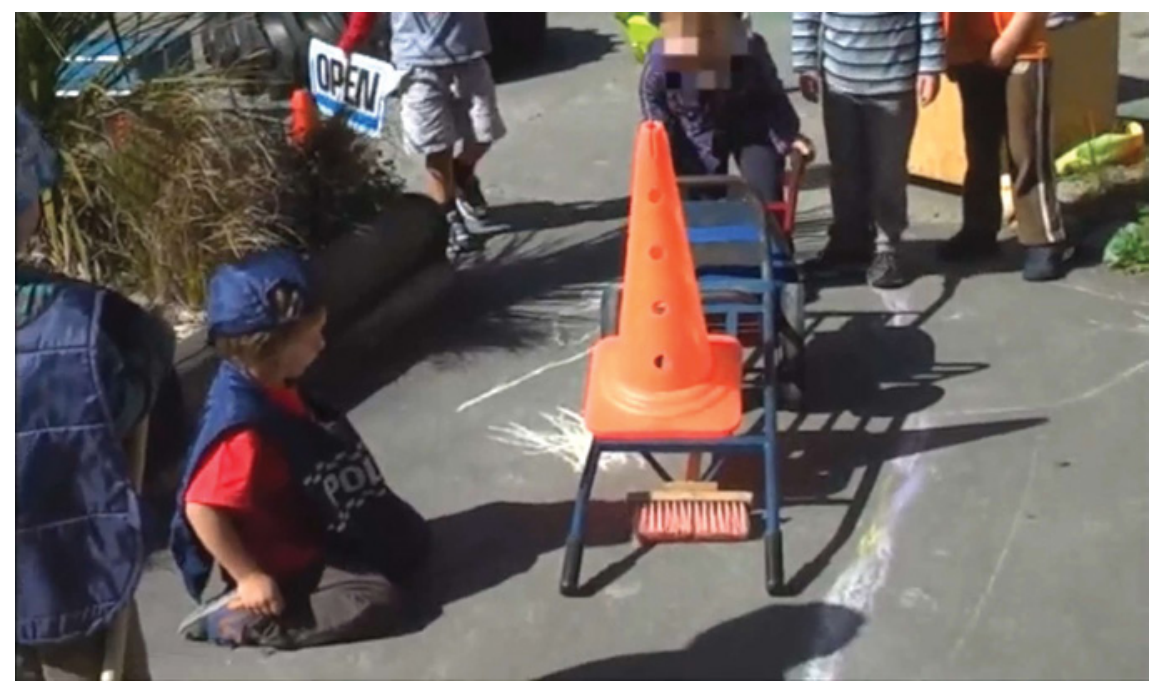

FIGURE 1 The broom-machine (see here)

Witnessing the exhilaration the performing broom-machine activates, both first-hand and via the playback of video-recordings, and for both researchers and viewers, opens up possibilities for engaging with "how material thingsin effect-'act back' and continually affect and/or effect us" (Horton \& Kraftl, 2006, p. 73). As "[s]omething delightful and hilarious comes into play" (Kind, 2013, p. 437), through the "coming into being of something unexpected" (Haraway, 2008, p. 368), there is a sense of animation many who witness it find themselves infused by. The event illustrates well the notion of curriculum as assemblage, including the generative role material resources played in its "congregational agency" (Bennett, 2010, p. 34). For example, integral to considering the self-and relations in operation here, and the possibilities these open up, was the call to consider the wealth of loose parts available at the Ec centre which lent themselves to making things that did things, or as Bennett might put it, things that had "thing-power" (p. 2).

What also engaged me as I watched and rewatched this episode and focused on the peer/friendship dynamic as part of the self-and relations in play, were the possibilities opened up by the readiness of the vehicle operator to take up Jacob's suggestion and Jacob's openess to having his suggestion reworked. I was reminded of Davies' (2010) call for pedagogy needing to foster an openness to becoming different in one's encounters with others. As Davies observes it is often the emergent quality of activity, a feature frequently found in children's play and play-based curricula, that can help to foster such "openness to what 
might happen next...an awareness of oneself-in-relation [and]...ways of knowing differently" (p. 6o).

In contrast to the possibilities Episode one offered as a case to think with about self-and relations to do with being open to being effected by the other, the events video-recorded in Episode two served as a case to think with about the potential for the practices of any group, including children, to be exclusionary and repressive in their effects. The video-recording of these events played a key role in helping bring attention to the way in which peer exclusions could be enacted in embodied ways that were subtle, nuanced and covert, and often under the radar of teachers. In addition these research dynamics were also and importantly a case to think with about the way video use intersected with issues of surveillance, exposure and risk and the ethics of what Barad (2007) and Haraway (2008) term researcher response-ability. This conception of responseability as "a relationship crafted in intra-action through which entities, subjects and objects come into being" (Haraway, 2008, p. 71), interlinks with the way Barad (2007) frames reseach as always already ethico-onto-epistemological. It is a call to attend to the real effects of our research projects and the multiply entangled dynamics of researcher-researched relations.

The dynamic I became caught up in when video-recording and re-watching the mat-time events in Episode two was the negative response to Sabal's attempts to connect with certain of his classmates. An unsuccessful effort to connect with his classmate Jarvis, starts with Sabal moving across the mat to sit on the floor next to him. Having watched Jarvis raise both arms up in the air, Sabal does the same. It is not apparent why Jarvis is sitting on the floor raising his arms. The other children are still standing up following the instructions of the student teacher. What is apparent is the negative response the camera registers when Jarvis catches sight of Sabal sitting alongside, the look of displeasure and the two half-shoves to get Sabal to move away.

The second event happens at the end of mat-time as the children leave to make their way to their allocated worktables. Vinnie, another of the boys Sabal has been making efforts to connect with, is still lying face-down on the mat; Sabal does the same. When Vinnie sits up and discovers Sabal lying alongside, he starts tapping Sabal on the back to rouse him. Sabal looks up with a tentative smile. Vinnie's response cannot be seen as his back is to the camera, but it serves to shut down any further overture from Sabal, as the two boys get to their feet and head away. 


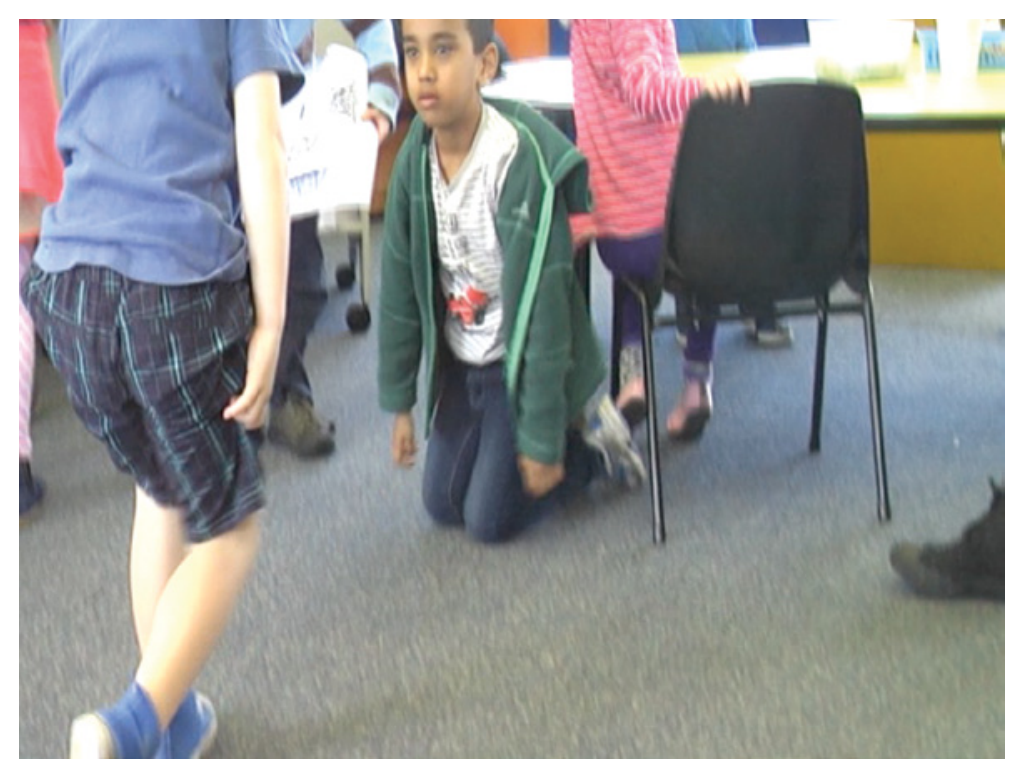

FIGURE 2 Classmates continued (see here)

Arriving at the decision to use video/visual data in the thesis to recount these events was an ethically fraught process. Content-wise, I selected two short video clips of the split-second interactions involving Jarvis and Vinnie, ensuring neither child was identifiable. Contrastingly, in the still-frame photo I also included, shown here in Figure 2, I chose to keep Sabal's face identifiable. I felt and still feel conflicted about my decision to do so. I thought it an image that spoke to Sabal's experience of events more directly than any verbal text I as researcher was able to author. Yet, as discussed further in the next section, I still continue to question the ethics of my decision and whether I was considerate enough of the potential negative effect using this image might entail for Sabal.

\section{Entanglements of Possibilty, Risk, Surveillance, Exposure and Response-ability}

The risk of videoed-observations in this study being experienced by participants as unwanted surveillance was an ongoing methodological and ethical concern. It was a risk that in part was tied in with the relative lack of control I as researcher often found myself able to exercise over what was caught on camera. Such entangled researcher-apparatus relations resonate with the 
sort Bhatt and de Roock (2013) identify in discussing the methodological implications of using video in their classroom-based research, when they refer to the way in which "decisions were also made for us by the apparatus we used" (p. 9).

Crucially too, the undertaking to pass video recordings back to participants, while an endeavour on my part to help democratise the research process, exacerbated that risk. While these aspects seemed not to be an issue when it came to recording and passing back to participants an episode such as the broommachine, I found the research dynamics with/in the Episode two mat-time recordings were far more ethically entangled and entangling.

Whilst speculative at best to try to guage the effects on Sabal and his parents of watching the new entrant classroom videoing, it did seem in the interview with Sabal's parents, that the invitation to revisit and provide feedback on the recordings facilitated an opening for broaching the matter of the exclusion and bullying Sabal was experiencing. These were matters Sabal's parents had thus far veered away from raising with Sabal's teacher.

Sabal's parents spoke in their interview of Sabal telling them he had "no friends" and that he was being picked on during break-times by some of his classmates. They also spoke of Sabal's efforts to "counteract" the situation with plans to "dress like Ben Ten and Spiderman .... and put his angry face on". Sabal's mother Sila recounted how she decided to visit the school at break time to invesitgate further:

For a few days I went during the lunch break... because I wanted to see what he does... He actually goes and hides. For an hour. Until it's time to start class and then he comes. He hides so that he doesn't get picked on. And I felt really sad because one of the days it was raining, and he was outside, I think, hiding somewhere.

In my interview with Sabal I was somewhat reassured by how relieved he seemed to be able to speak of the exclusions and bullying he had experienced and how pleased he seemed to have his parents and my support. However I could also sense his discomfort and was concerned about how difficult and painful disclosure around such sensitive matters can be (Pihkala, Huuki \& Sunnari, 2019). This clearly did not seem the time to attempt revisiting video content let alone the question of its dissemination.

When I later made the decision to approach Sabal's parents to ask if they would act as intermediary, they came back to me saying that they and Sabal "were fine" with me incorporating the material I had asked to use. Yet I remain uneasy about the extent to which I came to rely on the assurances of Sabal's 
parents, and continue to question whether I acted with enough responseabilty for Sabal's interest.

When I met up with Sabal's teacher to pass over and discuss the $\mathrm{PhD}$ report chapter on Sabal's experiences as a new entrant the entanglements grew. She was clearly upset by the excerpts from Sabal's parents' interview and struggled to understand why they had not come to her. She was also upset by the idea that classroom dynamics could be serving to foster exclusion and bullying, intolerance of difference and racial bias. Remembering the kindly, hardworking, highly thoughtful practice I had often witnessed in her classroom, I found myself torn between wishing I was not having to doing this and the responsibility I saw myself carrying for what I had undertaken to do. Returning to Lather's (2016) framing of agency as "enactment in the possibilities and responsibilities of reconfiguring entanglements" (p. 126), I asked myself "would/ could I have done any better than Sabal's teacher, in the same circumstances?', and was met with the answer "Quite possibly not". Yet it is in the spirit of wanting to engage with the idea of researcher response-ability as actively working to reconfigure such entanglements toward better possible futures, that I put up for discussion the events of these vexed research relations (Peters et al., 2020).

Methodological texts dealing with the use of video in research with young children typically suggest this involves particular ethical challenges, with researchers commonly advised to attend to the assymmetries of power between child/children and researcher, and adults (teachers parents) and children (Abebe \& Bessell, 2014). As the discussion above serves to highlight this is ethically risky terrain and critical advice to heed. In addition though, as the discussion above further highlights, these need not only or at all times be the dynamics of most immediate concern. This study helps point to the need for the power dynamics of children's relationships to receive greater research attention (MacNaughton, 2003). These were dynamics video revealed particularly starkly. As this article underscores there are both possibilities and risks in seeking to do better by children's perspectives.

This article draws attention to the enriched opportunites video allows for exploring young children's modes of being, doing, knowing and becoming in a way that recognises and engages with the human and more-than-human. I do not claim here to have done justice to the complex and shifting entanglement of forces, phenomena and circumstances at work in the events 
discussed. However I would suggest that the examples offered and discussed in this article are a call to engage with the entangled relations of possibility and risk in the research use of video (Murris \& Menning, 2019), to engage with what it means to enact response-able research with/in the use of this apparatus (Barad, 2007), and to engage with whether the potential advantages of possibly learning more about the worlds of young children "outweigh the possibility that we might be indeed invading their worlds" (Sumsion et al., 2011, p. 125).

\section{Acknowledgements}

With grateful thanks to the journal editors and my three reviewers for their full, thoughtful and enormously useful feedback.

\section{References}

Abebe, T. \& Bessell, S. (2014). Advancing ethical research with children: Critical reflections on ethical guidelines. Children's Geographies, 12(1), 126-133. https://www.doi .org/10.1080/14733285.2013.856077.

Alaimo, S., \& Hekman, S. (Eds.). (2008). Material feminisms. Indiana University Press. Änggård, E. (2013). Digital cameras: Agents in research with children. Children's Cartographies, 13(1), 1-13. https://www.doi.org/10.1080/14733285.2013.827871.

Barad, K. (2007). Meeting the universe halfway. Duke University Press.

Bennett, J. (2010). Vibrant matter: A political ecology of things. Duke University Press.

Bhatt, I., \& de Roock, R. (2013). Capturing the sociomateriality of digital literacy events. Research in Learning Technology, 21(1), 1-19. https://www.doi.org/10.3402/rlt.v21 .21281.

Colebrook, C. (2002). Gilles Deleuze. Routledge.

Davies, B. (2010). The implications for qualitative research of the struggle between the individualised subject of phenomenology and the emergent multiplicities of the postructuralist subject: the problem of agency. Reconceptualizing Educational Research Methodology, 1(1), 54-68. https://www.doi.org/10.7577/rerm.171.

Davies, B. (2014). Listening to children: Being and becoming. Routledge.

De Freitas, E. (2013). What were you thinking? A Deleuzian/Guattarian analysis of communication in the mathematics classroom. Educational Philosophy and Theory, 45(3), 287-300.

Deleuze, G., \& Guattari, F. (1987). A thousand plateaus. Continuum. 
Dolphijn, R., \& van der Tuin, I. (2012). New materialism: Interviews \& cartographies. Retrieved from http://www.progressivegeographies.com/2012/10/16/new -materialism-interviews-cartographies.

Flewitt, R. (2005a). Conducting research with young children: Some ethical considerations. Early Child Development and Care, 175(6), 553-565. https://www.doi.org/ 10.1080/03004430500131338.

Flewitt, R. (2005b). Is every child's voice heard? Researching the ways 3-year-old children communicate and make meaning at home and in a pre-school playgroup. Early Years, 25(3), 207-222. https://www.doi.org/10.1080/09575140500251558.

Flewitt, R. (2006). Using video to investigate preschool classroom interaction: Education research assumptions and methodological practices. Visual Communication, 5(1), 25-51. https://www.doi.org/10.1177/1470357206060917.

Foucault, M. (1995). Discipline and punish: The birth of the prison (2nd ed.). Vintage.

Franks, A., \& Jewitt, C. (2001). The meaning of action in learning and teaching. British Educational Research Journal, 27(2), 201-218.

Haggerty, M. (2019). Navigating the entanglements: Curriculum and assessment priorities in transitioning to school in Aotearoa-New Zealand. [Doctoral dissertation, Victoria University of Wellington]. The research archive Victoria University of Wellington. http://hdl.handle.net/10063/8040.

Haraway, D. (2008). When species meet. University of Minnesota Press.

Horton, J., \& Kraftl, P. (2006). What else? Some more ways of thinking and doing 'Children's Geographies'. Children's Geographies, 4(1), 69-95. https://www.doi.org/ 10.1080/14733280600577459.

Kind, S. (2013). Lively entanglements: The doings, movements and enactments of photography. Global Studies of Childhood, 3(4), 427-441. https://www.doi.org/10.2304/ gsch.2013.3.4.427.

Kress, G. (2000). Multimodality: Challenges to thinking about language. TESOL Quarterly, 34, 337-340. https://www.doi.org/10.2307/3587959.

Kress, G. (2011). Discourse analysis and education: A multimodal social semiotic approach. In R. Rogers (Ed.), Critical discourse analysis in education( $2^{\text {nd }}$ ed., pp. 205-225). Taylor \& Francis.

Lather, P. (2016). Top ten+ list: (Re)thinking ontology in (post)qualitative research. Cultural Studies Cultural Methodologies, 16(2), 125-131. https://www.doi.org/ $10.1177 / 1532708616634734$.

Leander, K., \& Boldt, G. (2012). Rereading “A pedagogy of multiliteracies”: Bodies, texts, and emergence. Journal of Literacy Research, 45(1), 22-46. https://www.doi.org/10.11 77/1086296X12468587.

Lorimer, J. (2010). Moving image methodologies for more-than-human geographies. cultural geographies, 17(2), 237-258. https://www.doi.org/10.1177/1474474010363853. 
Luttrell, W. (2010). "A camera is a big responsibility": A lens for analyzing children's visual voices. Visual Studies, 25(3), 224-237. https://www.doi.org/10.1080/147258 6X.2010.523274.

Magnusson, L. (2018). Photographic agency and agency of photographs: Three-yearolds and digital cameras. Australasian Journal of Early Childhood, 43(3), 34-42. https://www.doi.org/10.23965/AJEC.43.3.04.

MacNaughton, G. (2003). Eclipsing voice in research with young children. Australian Journal of Early Childhood, 28(1), 36-42.

Mangen, A. (2010). Point and click: Theoretical and phenomenological reflections on the digitization of early childhood education. Contemporary Issues in Early Childhood, 11(4), 415-431. https://www.doi.org/10.2304/ciec.2010.11.4.415.

Mazzei, L., \& McCoy, K. (2010). Thinking with Deleuze in qualitative research. International Journal of Qualitative Studies in Education, 23(5), 503-509. https://www.doi .org/10.1080/09518398.2010.500634.

McNeill, D. (2000). Language and gesture. Cambridge University Press.

Murris, K., \& Menning, S. (2019). Introduction to the special issue: Videography and decolonizing childhood. Video Journal of Education and Pedagogy, 4, 1-13. https:// www.doi.org/10.1163/23644583-00401010.

Otrel-Cass, K., Cowie, B. \& Maguire, M. (2010).Taking video cameras into the classroom. Waikato Journal of Education, 15(2), 109-118.

Peters, M., White, E. J., Besley, T., Locke, K., Redder, B., Novak, R., Gibbons, A., O'Neill, J. Tesar, M. \& Sturm, S. (2020). Video ethics in educational research involving children: Literature review and critical discussion. Educational Philosophy and Theory. https://www.doi.org/10.1080/00131857.2020.1717920.

Pihkala, S., Huuki, T., \& Sunnari, V. (2019). Moving with touch: Entanglements of a child, Valentine's Day cards, and research-activism against sexual harassment in pre-teen peer cultures. Social Sciences, 8(226), 1-13. https://www.doi.org/10.3390/ socsci8080226.

Rose, G. (2012). Visual methodologies: An introduction to researching with visual methods. Sage.

Rutanen, N., Amorim, K. S., Marwick, H., \& White, J. (2018). Tensions and challenges concerning ethics on video research with young children: Experiences from an international collaboration among seven countries. Video Journal of Education and Pedagogy, 3(7), 1-14. https://www.doi.org/10.1186/s40990-018-0019-x.

Sellers, M. (2009). Re(con)ceiving children in curriculum: Mapping (a) milieu(s) of becoming [Doctoral dissertation, University of Queensland]. UQ: eSpace. https:// espace.library.uq.edu.au/view/UQ:180106.

Sparrman, A. \& Lindgren, A. (2010). Visual documentation as a normalizing practice: A new discourse of visibility in preschool. Surveillance and Society, 7(3/4), 248-261. 
Stephenson, A. (2010). Unravelling children's 'freedom of choice'. Early Childhood Folio, 14(2), 26-30.

Sumsion, J., Harrison, L., Press, F., McLeod, S., Goodfellow, J., \& Bradley, B. (2011). Researching infants' experiences of early childhood education and care. In D. Harcourt, B. Perry, \& T. Waller (Eds.), Researching young children's perspectives: Debating ethics and dilemmas of educational research with children (pp. 113-127). Routledge.

Taylor, C. A. (2016). Edu-crafting a cacophonous ecology: Posthumanist research practices for education. In C. A. Taylor (Ed.), Posthuman research practices in education (pp. 5-24). Palgrave MacMillan.

Wohlwend, K. (2011). Mapping modes in children's play and design: An action-oriented approach to critical multimodal analysis. In R. Rogers (Ed.), An introduction to critical discourse analysis in education (2nd ed., pp. 242-266). Taylor \& Francis. 